\title{
Prevalence and Possible Risk Factors of Overactive Bladder Symptoms in Women Living in the City of Izmir
}

\section{Izmir Ilinde Yaşayan Kadınlarda Aşııı Aktif Mesane Semptomlarının Prevalansı ve Olası Risk Faktörleri}

\author{
(D) Bora İrer ${ }^{1}$, (D) Volkan Şen², (D) Ozan Bozkurt², (D) Ömer Demir ${ }^{2}$, (D) Adil Esen² \\ ${ }^{1}$ Izmir Metropolitan Municipality Eşrefpaşa Hospital, Clinic of Urology, Izmir, Turkiye \\ ${ }^{2}$ Dokuz Eylül University Faculty of Medicine, Department of Urology, Izmir, Turkiye
}

\section{What's known on the subject? and What does the study add?}

Overactive bladder is a condition that affects quality of lif and daily social, emotional and physical activities of patients. This study aims to evaluate the prevalence and possible risk factors of overactive bladder symptoms among women living in a western city of Turkiye, İzmir.

\begin{abstract}
Objective: We aimed to evaluate the prevalence and possible risk factors of overactive bladder symptoms (OABS) among women living in a western city of Turkiye, İzmir.

Materials and Methods: A questionnaire and the validated Overactive Bladder Symptom Score were filled by urologists with face-to-face interview. The prevalence of OABS and independent possible risk factors of OABS such as age, obesity, systemic diseases, educational level, marital status and number of births were analyzed. The participants with OABS and without OABS were compared in terms of possible risk factors.

Results: A total of 719 women were included and the prevalence of OABS was $42.8 \%$ in our study. The prevalence of OABS with urinary incontinence (UI) $\left(O A B_{\text {wet }}\right)$ was $69.2 \%$ and the prevalence of $O A B S$ without $\mathrm{UI}\left(O A B_{d r y}\right)$ was $30.8 \%$ and nocturia was the most common $0 A B S$ besides urgency. There was a statistically significant association between OABS and presence of nocturia and UI types $(r=0.363, p<0.001, r=0.568, p<0.001)$. The key risk factors for OABS according to multivariate analysis were obesity, hypertension, diabetes mellitus, marital status and lower education level.

Conclusion: The prevalence of OABS was $42.8 \%$ among adult Turkish women in the city of İzmir. Obesity, hypertension, diabetes mellitus, lower education and being married were significantly related to OABS in women.
\end{abstract}

Keywords: Overactive bladder symptoms, Prevalence, Risk factors, Urinary incontinence

Öz

Amaç: Türkiye'nin batı kenti İzmir'de yaşayan kadınlarda aşırı aktif mesane semptomlarının (AAMS) prevalansını ve olası risk faktörlerini değerlendirmeyi amaçladık.

Gereç ve Yöntem: Validasyonu yapılmış Aşırı Aktif Mesane Semptom Skoru (OABSS) formunu içeren anket, katılımcılarla yüz yüze görüşme ile ürologlar tarafından dolduruldu. AAMS prevalansı ve yaş, obezite, komorbidite, eğitim düzeyi, evlilik durumu ve doğum sayısı gibi AAMS'nin bağımsız olası risk faktörleri değerlendirildi. AAMS olan ve olmayan katılımcılar olası risk faktörleri açısından karşılaştırıldı.

Bulgular: Çalışmamıza toplam 719 kadın dahil edildi ve AAMS prevalansı \%42,8 idi. İdrar kaçırma ile birlikte olan AAMS prevalansı \%69,2, idrar kaçırma birlikteliği olmaksızın AAMS prevalansı \%30,8 olarak bulundu ve acil sıkışma hissi ile birlikte en sık görülen semptom noktüriydi. AAMS ile noktüri ve idrar kaçırma tipleri arasında istatistiksel olarak anlamlı ilişki vardı $(r=0,363, p<0,001, r=0,568, p<0,001)$. Çok değişkenli analize göre AAMS için temel risk faktörleri obezite, hipertansiyon, diabetes mellitus, evlilik durumu ve düşük eğitim seviyesi idi.

Sonuç: İzmir ilindeki yetişkin Türk kadınlarında AAMS prevalansı \%42,8 idi. Obezite, hipertansiyon, diabetes mellitus, düşük eğitim ve evli kadınlar arasında AAMS ile anlamlı ilişki vardı.

Anahtar Kelimeler: Aşırı aktif mesane semptomları, Prevalans, Risk faktörleri, İdrar kaçırma

Correspondence: Bora İrer MD, İzmir Metropolitan Municipality Eşrefpaşa Hospital, Clinic of Urology, İzmir, Turkiye

E-mail: borairer@yahoo.com ORCID-ID: orcid.org/0000-0002-7719-9033

Received: 17.05.2018 Accepted: 22.05.2018

Cite this article as: İrer B, Sen V, Bozkurt O, Demir Ö, Esen A. Prevalence and Possible Risk Factors of Overactive Bladder Symptoms in Women Living in the City of İzmir. J Urol Surg 2018;5(3):180-187.

- Copyright 2018 by the Association of Urological Surgery / Journal of Urological Surgery published by Galenos Publishing House. 


\section{Introduction}

Overactive bladder $(O A B)$ is a condition that affects healthrelated quality of life and daily social, emotional and physical activities of patients (1). The International Continence Society (ICS) defines $O A B$ as urgency, with or without urgency urinary incontinence (UUI), usually with frequency and nocturia (2). In several population-based studies, the prevalence of $O A B$ symptoms (OABS) has been reported to be between $11 \%$ and $32.6 \%(3,4,5)$. Although patients with OABS (with or without UUI) have-high level depression, sexual problems, and distress in daily life, most patients do not consult a doctor for any treatment and continue to suffer from OABS (3).

The underlying causes of the pathophysiology of OABS have not been fully established. For this reason, many studies have been conducted in many countries to establish the causes and risk factors for OABS in their populations. Aging, chronic diseases, such as diabetes mellitus (DM) and hypertension, obesity, socioeconomic status, being married and childbirth have been shown to be associated with $\operatorname{OABS}(5,6,7,8,9,10)$.

There are several studies in the literature comparing the risk factors for OABS, lower urinary tract symptoms and urinary incontinence (UI) in the Turkish population and showing the effect of these conditions on the quality of life of patients $(11,12,13)$. In this study, we aimed to evaluate the prevalence and possible risk factors for OABS and severity of OABS among adult women living in a western city of Turkiye, İzmir, with faceto-face interviews by experienced urologists.

\section{Materials and Methods}

This study was approved by the Ethics Committee of Dokuz Eylül University with number 2016/05-35. The cohort included all women over 18 years of age who accepted to participate in the study and completed the informed consent form on a weekend for International Women's Day Campaign at İzmir International Fair. The questionnaire used in the study was completed by participants during face-to-face interviews with urologists. Participants who were unable to respond to questionnaire due to cognitive disability and who had dementia or any neurological disease were excluded from the study. Also women having symptoms of cystitis, such as dysuria and fever, and those receiving antibiotic therapy for urinary tract infections were excluded from the study.

The questionnaire consisted of 2 parts. Socioeconomic and demographic features such as age, occupation, level of education, parity, marital status, and physician referral status, as well as systemic diseases such as hypertension, DM, coronary artery disease, chronic obstructive pulmonary disease, etc. and previous operation history were evaluated in the first part; the validated International Consultation on Incontinence Questionnaire-Short Form (ICIQ-SF) (14) and Overactive Bladder Symptom Score (OABSS) (15) were administered in all participants in the second part. Definitions for OABS and UI types were used according to the standard definitions of the ICS (2). The 8-item Overactive Bladder Questionnaire (OAB-V8) consists of 8 questions each of which can be graded by the patient within a scale of never (0); few (1); sometimes (2); quite a few (3); usually (4); and always (5). Thus, the total score ranges from a minimum of 0 to a maximum of 40 . A total score of 8 or greater on the OABSS indicates high risk for OAB (15). Therefore, for subsequent analysis, we classified women with an OABSS greater than 8 as having OABS (group 1) and women with an OABSS less than 8 as having no OABS (group 2). The participants with or without OABS were evaluated in terms of risk factors such as age, comorbidities, parity, presence or absence of incontinence, status of doctor consultation, education level, marital status and total ICIQ-SF score and OABSS. The participants were also divided into 3 groups according to age distributions and each group was evaluated in terms of OABS status.

\section{Statistical Analysis}

Categorical variables were compared with chi-square test and continuous variables were compared with independent samples t-test. Multivariate regression analysis was used to define the potential risk factors for OAB. The results were expressed as adjusted odds ratio with 95\% confidence interval. Statistical analyses were performed with Statistical Package of Social Sciences version 22.0 (SPSS, Chicago, Illinois, United States of America) and a $p$ value of less than 0.05 was considered statistically significant.

\section{Results}

The mean age of 719 women participating in the study was $51.2 \pm 11.1$ years. Socioeconomic and demographic characteristics, comorbidities, UI status and OABS of the participants are presented in Table 1. The prevalence of OABS was $42.8 \%$ and the prevalence of $\mathrm{UI}$ was $50.3 \%$ in the study. In the participants with OABS, the prevalence of OABS with $\mathrm{UI}\left(O \mathrm{OB}_{\text {wet }}\right)$ was $69.2 \%$ and the prevalence of OABS without $\mathrm{UI}$ $\left(O A B_{d r y}\right)$ was $30.8 \%$. In this study, the incidence of frequency, nocturia, UUI was found to be $72.3 \%, 61.8 \%, 42.7 \%$ and $37.7 \%$, respectively. In our study, $86.7 \%$ of participants with OABS consulted a doctor previously, whereas $13.3 \%$ of participants did not consult a doctor $(p<0.001)$.

In this study, we showed using univariate analysis that the most significant potential risk factors associated with OABS were age $(p<0.001), D M(p<0.001)$, hypertension $(p<0.001)$, parity $(p<0.001)$, education level $(p=0.002)$, marital status $(p<0.001)$ and 
obesity $(p<0.001)$ (Table 2$)$. However, there were no statistically significant relationship between OABS and the other possible risk factors (Table 2). Patients with OABS had more frequent UI and nocturia than patients without OABS (Table 3 ). In addition,

Table 1. Socioeconomics and demographic characteristics, comorbidities, continence and overactive bladder symptoms status of participants

\begin{tabular}{|c|c|}
\hline Age (mean \pm SD) & $51.2 \pm 11.1$ \\
\hline Number of births (parity) (range) & $1.8(0-10)$ \\
\hline Overactive Bladder Bymptom Score (mean \pm SD) & $9.0 \pm 8.6$ \\
\hline ICIQ-SF Score (mean \pm SD) & $4.1 \pm 5.1$ \\
\hline $\mathrm{BMI}($ mean $\pm \mathrm{SD})$ & $28.7 \pm 3.3$ \\
\hline \multicolumn{2}{|l|}{ Age group } \\
\hline$\leq 40$ years $(n, \%)$ & $119(16.6 \%)$ \\
\hline $40-60$ years $(n, \%)$ & $472(65.6 \%)$ \\
\hline$\geq 60$ years $(n, \%)$ & $128(17.8 \%)$ \\
\hline \multicolumn{2}{|l|}{ Marital status } \\
\hline Never married $(\mathrm{n}, \%)$ & $88(12.2 \%)$ \\
\hline Divorced $(n, \%)$ & $125(17.4 \%)$ \\
\hline Married (n, \%) & $506(70.4 \%)$ \\
\hline \multicolumn{2}{|l|}{ Education level } \\
\hline Primary and secondary school $(n, \%)$ & $310(43.1 \%)$ \\
\hline High school (n, \%) & $225(31.3 \%)$ \\
\hline College and higher education $(n, \%)$ & $184(25.6 \%)$ \\
\hline \multicolumn{2}{|l|}{ Comorbidities } \\
\hline Diabetes mellitus ( $\mathrm{n}, \%)$ & $100(13.9 \%)$ \\
\hline Hypertension (n, \%) & $238(33.1 \%)$ \\
\hline Thyroid diseases $(n, \%)$ & $28(3.9 \%)$ \\
\hline Coronary artery disease $(n, \%)$ & $34(4.7 \%)$ \\
\hline Chronic obstructive pulmonary disease (n, \%) & $8(1.1 \%)$ \\
\hline \multicolumn{2}{|l|}{ Number of births (parity) } \\
\hline Nulliparous (n, \%) & $128(17.8 \%)$ \\
\hline$<3$ births $(n, \%)$ & $442(61.5 \%)$ \\
\hline$\geq 3$ births $(n, \%)$ & $149(20.7 \%)$ \\
\hline \multicolumn{2}{|l|}{ Urinary incontinence } \\
\hline Yes & $362(50.3 \%)$ \\
\hline No & $357(49.7 \%)$ \\
\hline \multicolumn{2}{|l|}{ Urinary incontinence types } \\
\hline Stress UI $(n, \%)$ & $250(69.1 \%)$ \\
\hline Urge UI (n, \%) & $62(17.1 \%)$ \\
\hline Mixed UI $(n, \%)$ & $50(13.8 \%)$ \\
\hline \multicolumn{2}{|l|}{ Overactive Bladder Symptom Score $\geq \mathbf{8}$} \\
\hline Yes (group 1) & $308(42.8 \%)$ \\
\hline No (group 2) & $411(57.2 \%)$ \\
\hline \multicolumn{2}{|l|}{ Status of doctor consultation } \\
\hline Yes & $393(54.7 \%)$ \\
\hline No & $326(45.3 \%)$ \\
\hline
\end{tabular}

there were statistically significant association and correlation between OABS severity and presence of nocturia and UI types $(r=0.363, p<0.001, r=0.568, p<0.001)$. When we examined the relationship of age with $\mathrm{OABS}$ severity and storage symptoms, we found a statistically significant difference between age groups in terms of OABS severity and storage symptoms especially nocturia and UI (Table 4). Body mass index (BMI), total OABSS and frequency of nocturia increased with age (Table 4).

According to our results, major risk factors for OABS were DM, hypertension, obesity, marital status and low level of education in multivariate logistic regression analysis (Table 5). When we evaluated univariate and multivariate analyses, we found that some variables showed different relationships with OABS. There was a statistically significant difference in age and parity between participants with and without OABS $(p<0.001)$ (Table 2 ), whereas the statistical significance was not observed in multivariate analysis (Table 5).

\section{Discussion}

$O A B$ is a chronic disease and it is defined by the ICS as urgency, with or without UUI, usually with frequency and nocturia (2). The present study was designed as a community-based survey to evaluate the risk factors and the prevalence of OABS in women, living in İzmir, a western city of Turkiye. In our study population, the prevalence of OABS was $42.8 \%$. According to age groups, the prevalence of $O A B$ was $27.7 \%$ in those below 40 years of age, $44.9 \%$ in those aged $40-60$ years, and $49.2 \%$ in women above 60 years of age. The European Prospective Investigation into Cancer and Nutrition study showed that the global prevalence of OABS was $11.8 \%$ and $51 \%$ of men and $56 \%$ of women aged 40-59 years suffered from storage symptoms (3). In two different studies conducted in Japanese women, the prevalence of OABS was ranged between $8.1 \%$ and $\% 11(6,7)$. Kim et al. (8) reported that the prevalence of OABS was approximately 5.2\% among adult Korean women. The prevalence of OABS was found to be $6.0 \%$ in the Chinese population (9). The differences between the prevalence rates in our study and other studies may be related to inclusion criteria, such as age, race, systemic diseases, definition variety of $O A B S$, design of questionnaires and survey methods. Most of these studies were planned at outpatient clinics and the participants were interviewed via telephone or internet and the OABSS questionnaire was not used for determination of OABS. Although reaching a wider range of participants in surveys conducted via telephone and internet, the disadvantage of such studies is the time allocated for participation is limited and attendees' participation in the questionnaires is low. For these reasons, it may be more difficult to evaluate the actual situation of participants during telephone and internet interviews than in face-to-face interviews. This may lead to differences in OABS 
Table 2. Distribution of potential risk factors between overactive bladder symptoms groups

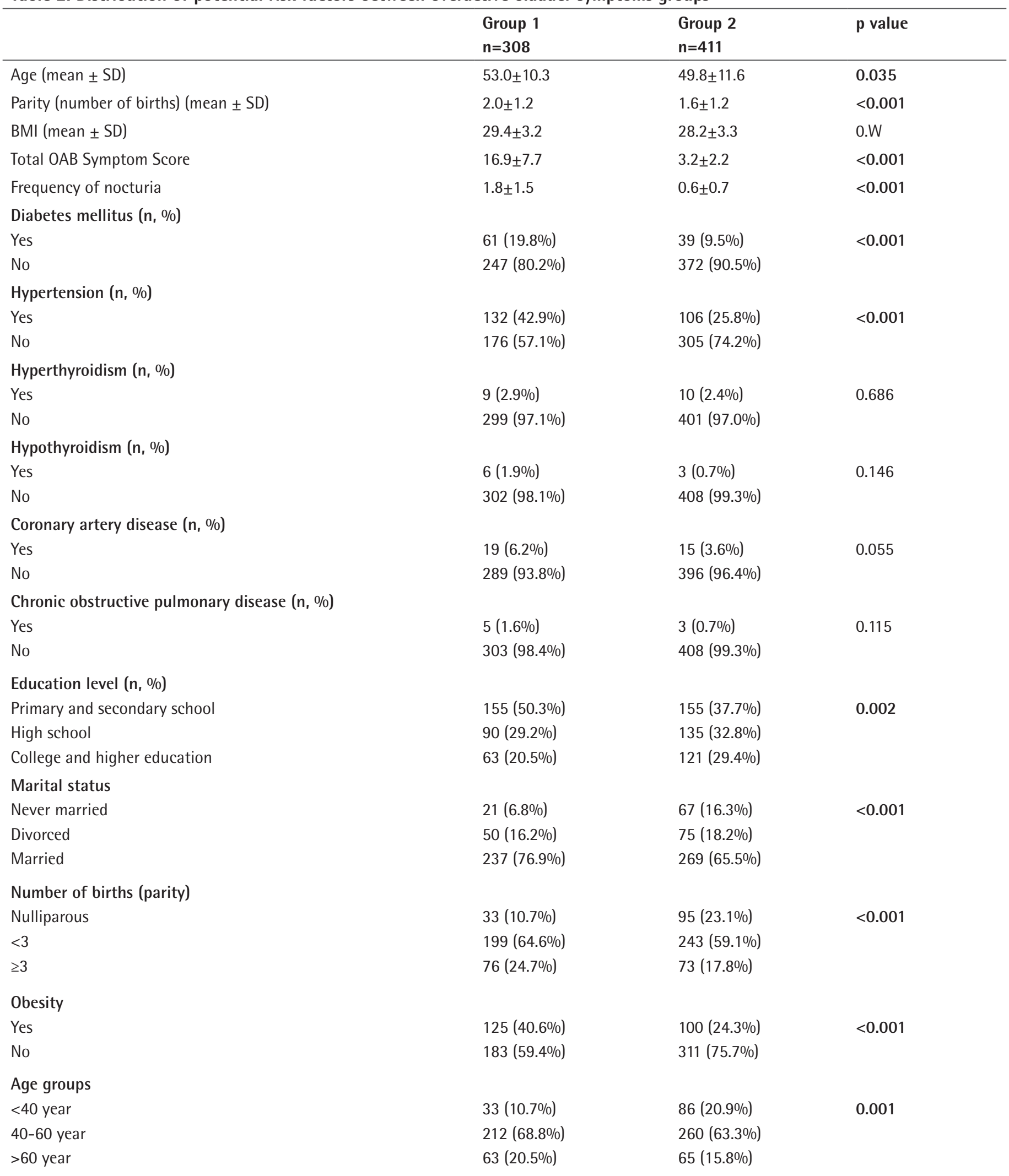

OAB: Overactive bladder, SD: Standard deviation, BMI: Body mass index

One-way ANOVA test for continuous variable and chi-square test for categorical variable 
Table 3. Relationship of presence of overactive bladder symptoms with urinary incontinence types and nocturia

\begin{tabular}{|c|c|c|c|c|}
\hline & Group $1(n=308)$ & Group $2(n=411)$ & $p$ value & $r$ value \\
\hline \multicolumn{5}{|c|}{ UI types $(n, \%)$} \\
\hline None UI & 47 (15.3\%) & $310(75.4 \%)$ & & \\
\hline UUI & $51(16.6 \%)$ & $11(2.7 \%)$ & $<0.001$ & 0.568 \\
\hline SUI & $162(52.6 \%)$ & $88(21.4 \%)$ & & \\
\hline MIU & $48(15.6 \%)$ & $2(0.5 \%)$ & & \\
\hline \multicolumn{5}{|c|}{ Nocturia $(\mathrm{n}, \%)$} \\
\hline Yes & $253(82.1 \%)$ & $220(53.5 \%)$ & $<0.001$ & 0.363 \\
\hline No & $55(17.9 \%)$ & $191(46.5 \%)$ & & \\
\hline
\end{tabular}

Table 4. Distribution of overactive bladder symptoms severity, storage symptoms, body mass index and frequency of nocturia according to age groups

\begin{tabular}{|c|c|c|c|c|}
\hline & $\begin{array}{l}\leq 40 \text { year } \\
n=119\end{array}$ & $\begin{array}{l}40-60 \text { year } \\
n=472\end{array}$ & $\begin{array}{l}60 \text { year< } \\
n=128\end{array}$ & $p$ value \\
\hline \multicolumn{5}{|l|}{ Frequency $(n, \%)$} \\
\hline No & $34(28.4 \%)$ & $126(26.7 \%)$ & $39(30.5 \%)$ & 0.679 \\
\hline Yes & $85(71.6 \%)$ & $346(73.3 \%)$ & $89(69.5 \%)$ & \\
\hline \multicolumn{5}{|l|}{ Urgency $(n, \%)$} \\
\hline No & $74(62.2 \%)$ & $271(57.4 \%)$ & $67(52.3 \%)$ & 0.294 \\
\hline Yes & $45(37.8 \%)$ & $201(42.6 \%)$ & $61(47.7 \%)$ & \\
\hline \multicolumn{5}{|l|}{ Nocturia $(n, \%)$} \\
\hline Yes & $51(42.9 \%)$ & $191(40.5 \%)$ & $33(25.8 \%)$ & 0.005 \\
\hline No & $68(57.1 \%)$ & $281(59.5 \%)$ & $95(74.2 \%)$ & \\
\hline \multicolumn{5}{|l|}{ UUI (n, \%) } \\
\hline Yes & $90(75.6 \%)$ & $286(60.6 \%)$ & $72(56.3 \%)$ & 0.003 \\
\hline No & $29(24.4 \%)$ & $186(39.4 \%)$ & $52(43.8 \%)$ & \\
\hline \multicolumn{5}{|l|}{ OABSS $\geq 8$} \\
\hline No & $86(72.3 \%)$ & $260(55.1 \%)$ & $65(50.8 \%)$ & 0.001 \\
\hline Yes & $33(27.7 \%)$ & $212(44.9 \%)$ & $63(49.2 \%)$ & \\
\hline $\mathrm{BMI}($ mean $\pm \mathrm{SD})$ & $28.2 \pm 3.1$ & $28.7 \pm 3.4$ & $29.5 \pm 3.0$ & 0.003 \\
\hline Total OABSS (mean \pm SD) & $6.6 \pm 7.6$ & $9.2 \pm 8.6$ & $10.7 \pm 9.0$ & 0.001 \\
\hline Frequency of nocturia (mean \pm SD) & $0.8 \pm 1.0$ & $1.1 \pm 1.3$ & $1.4 \pm 1.3$ & 0.002 \\
\hline
\end{tabular}

UUI: Urgency urinary incontinence, BMI: Body mass index, SD: Standard deviation, OABSS: Overactive Bladder Symptom Score Pearson's correlations and chi-square test for categorical variable

prevalence. Unlike previous studies, according to the best of our knowledge, our study was the first community-based study designed as face-to-face interviews and the OABSS was filled by experienced urologists.

There are few studies evaluating the prevalence of OABS in Turkiye. Zumrutbas et al. (11) reported that the prevalence of storage symptoms was $64.1 \%$ in women in a western city of Turkiye, Denizli. In our study, the prevalence of frequency, nocturia, urgency and UUI was found to be $72.3 \%, 61.8 \%$, $42.7 \%$ and $37.7 \%$, respectively.
OABS is defined by the ICS as wet and dry for more precise diagnosis of $O A B$ and for more effective treatment. Most of studies in the literature have found different results on the prevalence of $O A B_{d r y}$ and $O A B_{\text {wet }}$. Wang et al. (9) showed that the prevalence of $0 A B_{\text {wet }}$ was $70.0 \%$ and the prevalence of $O A B_{\text {dry }}$ was $30.0 \%$ among individuals with OAB. Wen et al. (10) showed that the $O A B_{\text {dry }}-$ to- $O A B_{\text {wet }}$ ratio was about 1:1. In present study, the prevalence of $O A B_{\text {wet }}$ was $69.2 \%$ and the prevalence of $O A B_{\text {dry }}$ was $30.8 \%$ in individuals with $O A B$ and the $O A B_{\text {dry }}$-to$O A B_{\text {wet }}$ ratio was about 2.3:1. Similar to the differences in the 
Table 5. Potential risk factors associated with overactive bladder symptoms

\begin{tabular}{|c|c|c|c|c|}
\hline \multirow[b]{2}{*}{ Variable } & \multicolumn{4}{|c|}{ Overactive bladder symptoms } \\
\hline & $\begin{array}{l}\text { B } \\
\text { coefficient }\end{array}$ & $\begin{array}{l}\text { Odds } \\
\text { ratio }\end{array}$ & $95 \% \mathrm{Cl}$ & $\mathbf{p}$ \\
\hline Age & 0.011 & 1.012 & $0.995-1.028$ & 0.176 \\
\hline Diabetes mellitus & -0.485 & 0.616 & $0.384-0.989$ & 0.045 \\
\hline Hypertension & -0.532 & 0.588 & $0.412-0.839$ & 0.003 \\
\hline $\begin{array}{l}\text { Parity (>2 } \\
\text { delivery) }\end{array}$ & 0.318 & 1.374 & $0.819-2.307$ & 0.229 \\
\hline Obesity & -0.734 & 0.480 & $0.344-0.670$ & $<0.001$ \\
\hline $\begin{array}{l}\text { Marital status } \\
\text { (married) }\end{array}$ & -0.509 & 0.601 & 0.404-0.893 & 0.012 \\
\hline $\begin{array}{l}\text { Education level } \\
\text { (primary school) }\end{array}$ & 0.501 & 1.650 & $1.093-2.490$ & 0.017 \\
\hline
\end{tabular}

B: Beta regression coefficient, Cl: Confidence interval

Multivariate regression analyses

studies of the OABS prevalence, the cause of the difference may be related to study design and age, gender and comorbid conditions of the participants involved in the study.

Many studies in the literature aimed to determine the risk factors for OABS. Possible risk factors for OABS include advanced age, obesity, hypertension, drug use, lower educational level, marital status, parity, and alcohol consumption $(8,9,10)$. In present study, according to multiple logistic models, DM, hypertension, being married, low education level and obesity were associated risk factors for OABS.

Previous researchers have pointed to an increase in the prevalence of OABS associated with aging $(3,8,9)$. This increase may be explained by aging processes that cause deterioration of the bladder functions due to decreased muscle and neurological activities, changes in physical status by aging and age-related factors such as menopause and systemic diseases. In this study, patients with OABS were older than those without OABS. As the age increased, frequency of OABS, especially nocturia and $\mathrm{UI}$, also increased. Moreover, we found that aging-related systemic diseases such as DM, obesity and hypertension were key risk factors for OABS.

Previous studies reported that there was an association between DM and OABS $(8,9,16)$. In addition, Kaplan et al. (17) examined the urodynamic findings in DM patients and found detrusor overactivity in 55\% of patients. One of the late complications of DM is peripheral neuropathy (17). The cause of diabetic neuropathy includes impaired glucose metabolism, ischemia, superoxide-induced free radical formation, damaged axonal transport, and metabolic derangement of the Schwann cell resulting in segmental demyelination and impairment of nerve conduction (18). Therefore, peripheral neuropathy can cause detrusor overactivity and may be an important risk factor for
OABS (19). Consistent with the literature, in our study, DM was a significant risk factor for OABS.

Obesity was demonstrated to be a risk factor that was significantly associated with OABS in several studies $(8,9,10,20)$. A patient with a BMI greater than $30 \mathrm{~kg} / \mathrm{m}^{2}$ is at increased risk for the onset of $\operatorname{OABS}(20,21)$. Our results showed a significant association between OABS and obesity. This association can be explained by mechanical, neuroendocrine and inflammatory factors. Obesity may increase bladder pressure which, in turn, causes or increases detrusor instability and results in OABS (22). On the other hand, adipose tissue may increase autonomic nerve activity by secreted leptin hormone, especially noradrenergic sympathetic nerves, and increased sympathetic activity results in urinary frequency (23). Furthermore, obesity is associated with a chronic inflammatory response resulting in oxidative stress, increased acute phase reactants, and activation of inflammatory signaling pathways (24). Due to the increase in concentrations of interleukin (IL)-1, IL-6, and tumor necrosis factor alpha in detrusor may result in overactivity (25).

In the literature, there are few studies linking hypertension to OABS $(8,26)$. However, there are many studies showing the relationship of $\mathrm{OAB}$ with hypertension and metabolic syndrome $(27,28,29)$. Kim et al. (8) showed significant associations between $\mathrm{OABS}$ and hypertension. Hypertension and vascular risk factors result in increased ischemia, which leads to structural changes in the bladder (30). Moreover, when the bladder blood flow decreases because of hypertension, adenosin triphoshate and prostaglandin E2 release from the urothelium and contractions occur in the bladder (31). Therefore, hypertension and vascular risk factors can lead to OABS. Similarly to the previous study, hypertension was found to be a risk factor for OABS in this study.

Low education level and being married are the possible risk factors of OABS in women. Previous studies and our study demonstrated a clear relationship between low education level and risk of OABS $(9,32)$. Smoking, poor hygiene and urinary tract infections may be more frequent in people with lower education levels, while those with higher education levels tend to search better health behaviors and consequently have a healthier lifestyle. However, there are conflicting results in the literature suggesting that being married was a risk factor for OABS. Similar to our results, Wang et al. (9) demonstrated that being married was a risk factor for OABS. On the contrary, Kim et al. (8) found that unmarried status was significantly related to OABS. The reason for this disparity may depend on the age, socioeconomic level, type of delivery and number of births of the participants.

Despite the considerable physical, social and psychological morbidity related with $\mathrm{OABS}$, many patients do not consult 
healthcare professionals. OABS, especially storage problems, may embarrass patients, thus, patients may not volunteer to talk to their doctor about these complaints. Additionally, patients with OABS may believe that no effective treatment was available for OABS. Milsom et al. (33) reported that $40 \%$ of individuals with OABS did not seek medical help. Üçer et al. (34) showed that 57\% of patients with $O A B$ symptoms had not been previously admitted to hospital. In our study, this rate was found to be $13.7 \%$.

\section{Study Limitations}

The current study has some limitations. First, we evaluated the participants on a weekend for International Women's Day Campaign at İzmir International Fair and in a limited time, the number of participants can be considered relatively small compared to previous studies. Second, urinalysis was not performed to identify urinary tract infections. However, the $O A B-V 8$ was filled by urologists during face-to-face interviews; patients, who complained of fever and dysuria and have recently been treated for cystitis, were identified with anamnesis and excluded from the study.

\section{Conclusion}

The prevalence of OABS in Turkish women was high and OABS affected almost half of the adult women and risk factors associated with OABS were similar to those in other countries. In accordance with the previous studies, obesity, medical comorbidities such as DM and hypertension, marital and low education were key risk factors for OABS and aging was associated with the presence of OABS and storage symptoms. According to the best of our knowledge, our study was the first community-based study designed as face-to-face interviews by experienced urologists. We assume that our study may contribute to the literature since it determines OABS prevalence and risk factors in women living in a western city of Turkiye, İzmir.

\section{Ethics}

Ethics Committee Approval: This study was approved by the Ethics Committee of Dokuz Eylül University with number 2016/05-35.

Informed Consent: All participitant completed the informed consent form.

Peer-review: Externally peer-reviewed.

\section{Authorship Contributions}

Surgical and Medical Practices: B.I., V.Ş., O.B., Ö.D., A.E., Concept: B.I.., V.Ş., O.B., Ö.D., A.E., Design: B.I.., V.Ş., O.B., Ö.D., A.E., Data Collection or Processing: B.I., V.Ş., Analysis or Interpretation: B.I., V.Ş., O.B., Literature Search: B.I.., Writing: B.I., O.B.
Conflict of Interest: No conflict of interest was declared by the authors.

Financial Disclosure: The authors declared that this study received no financial support.

\section{References}

1. Abrams P, Kelleher CJ, Kerr LA, Rogers RG. Overactive bladder significantly affects quality of life. Am J Manag Care 2000;6:580-590.

2. Abrams $P$, Cardozo L, Fall M, Griffiths $D$, Rosier $P$, Ulmsten $U$, van Kerrebroeck $P$, Victor A, Wein A; Standardisation Sub-committee of the International Continence Society. The standardization of terminology of lower urinary tract function: report from the standardization sub-committee of the International Continence Society. Neurourol Urodyn 2002;21:167-178.

3. Irwin DE, Milsom I, Hunskaar S, Reilly K, Kopp Z, Herschorn S, Coyne K, Kelleher C, Hampel C, Artibani W, Abrams P. Population-based survey of urinary incontinence, overactive bladder, and other lower urinary tract symptoms in five countries: results of the EPIC study. Eur Urol 2006;50:13061314.

4. Coyne KS, Sexton CC, Bell JA, Thompson CL, Dmochowski R, Bavendam T, Chen $\mathrm{Cl}$, Quentin Klemens J. The prevalence of lower urinary tract symptoms (LUTS) and overactive bladder (OAB) by racial/ethnic group and age: results from OAB-POLL. Neurourol Urodyn 2013;32:230-237.

5. Wang $Y, H u H, X u K$, Wang $X, N a Y$, Kang $X$. Prevalence, risk factors and the bother of lower urinary tract symptoms in China: a population-based survey. Int Urogynecol J 2015;26:911-919.

6. Homma Y, Yamaguchi O, Hayashi K; Neurogenic Bladder Society Commitee: An epidemiolgical survey of overactive bladder symptoms in Japan. BJU Int 2005;96:1314-1318.

7. Ninomiya S, Naito K, Nakanishi K, Okoyoma H. Prevalence and Risk Factors of Urinary Incontinence and Overactive Bladder in Japanese Women. Low Urin Tract Symptoms 2017.

8. Kim SY, Bang W, Choi HG. Analysis of the prevalence and factors associated with overactive bladder in adult Korean women. PLoS One 2017; 12:e0185592.

9. Wang $Y, X u K$, Hu H, Zhang $X$, Wang $X, N a Y$, Kang $X$. Prevalence, risk factors, and impact on health related quality of life of overactive bladder in Chia. Neurourol Urodyn 2011;30:1448-1455.

10. Wen JG, Li JS, Wang ZM, Huang CX, Shang XP, Su ZQ, Lu YT, Suo ZH, Wang $Y$, Qin GJ, Zhang WX, Heesakkers JP. The prevalence and risk factors of OAB in middle-aged people China. Neurourol Urodyn 2014;33:387-391.

11. Zumrutbas AE, Bozkurt Al, Tas E, Acar Cl, Alkis O, Coban K, Cetinel B, Aybek Z. Prevalence of lower urinary tract symptoms, overactive bladder and urinary incontinence in western Turkey: results of a population-based survey. Int J Urol 2014;21:1027-1033.

12. Kocak I, Okyay $P$, Dundar $M$, Erol $H$, Beser E. Female urinary incontinence in the west of Turkey: prevalence, risk factors and impact on quality of life. Eur Urol 2005;48:634-641.

13. Kaşıkçı $M$, Kılıç $D, A v s ̧ a r ~ G$, Şirin M. Prevalence of urinary incontinence in older Turkish women, risk factors, and effect on activities of daily living. Arch Gerontol Geriatr 2015;61:217-223.

14. Cetinel B, Ozkan B, Can G. The validation study of ICIQ-SF Turkish version. Turk J Urol 2004;30:332-338.

15. Tarcan T, Mangır N, Özgür MÖ, Akbal C. OAB-V8 Overactive Bladder Questionnaire Validation Study. Uroloji Bulteni 2012;21:113-116.

16. Liu RT, Chung MS, Lee WC, Chang SW, Huang ST, Yang KD, Chancellor MB, Chuang YC. Prevalence of overactive bladder and associated risk factors in 1359 patients with type 2 diabetes. Urology 2011;78:1040-1045. 
17. Kaplan $\mathrm{SA}$, Te $A E$, Blaivas JG. Urodynamic findings in patients with diabetic cystopathy. J Urol 1995;153:342-344.

18. Yoshimura N, Chancellor MB, Andersson KE, Christ GJ. Recent advances in understanding the biology of diabetes-associated bladder complications and novel therapy. BJU Int 2005;95:733-738.

19. Tai HC, Chung SD, Ho CH, Tai TY, Yang WS, Tseng $\mathrm{CH}$, Wu HP, Yu HJ. Metabolic syndrome components worsen lower urinary tract symptoms in women with type 2 diabetes. J Clin Endocrinol Metab 2010;95:1143-1150.

20. Dallosso HM, McGrother CW, Matthews RJ, Donaldson MM; Leicestershire MRC Incontinence Study Group. The association of diet and other lifestyle factors with overactive bladder and stress incontinence: a longitudinal study in women. BJU Int 2003;92:69-77.

21. Corcos J, Przydacz M, Campeau L, Gray G, Hickling D, Honeine C, Ramdoski $\mathrm{SB}$, Stothers L, Wagg A, Lond F. CUA guideline on adult overactive bladder. Can Urol Assoc J 2017;11:142-173.

22. Subak LL, Whitcomb E, Shen H, Saxton J, Vittinghoff E, Brown JS. Weight loss: a novel and effective treatment for urinary incontinence. J Urol 2005;174:190-195.

23. Shen J, Tanida M, Niijima A, Nagai K. In vivo effects of leptin on autonomic nerve activity and lipolysis in rats. Neurosci Lett 2007;416:193-197.

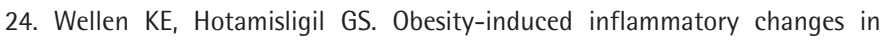
adipose tissue. J Clin Investig 2003;112:1785-1788.

25. Bouchelouche K, Alvarez S, Horn T, Nordling J, Bouchelouche. Human detrusor smooth muscle cells release interleukin-6, interleukin-8, and RANTES in response to proinfammatory cytokines interleukin- $1 \beta$ and tumor necrosis factor- $\alpha$. Urology 2006;67:214-219.

26. Yokoyama O, Yamagami H, Hiro S, Hotta S, Yoshida M. Efficacy and safety of fesoterodine treatment for overactive bladder symptoms in elderly women with and without hypertension. Int J Urol 2018;25:251-257.
27. Lua LL, Pathak P, Dandolu V. Comparing anticholinergic persistence and adherence profiles in overactive bladder patients based on gender, obesity, and major anticholinergic agents. Neurourol Urodyn 2017;36:2123-2131.

28. Bunn F, Kirby M, Pinkney E, Cardozo L, Chapple C, Chester K, Cruz F, Haap F, Kelleher C, Milsom I, Sievart KD, Tubaro A, Wagg A. Is there a link between overactive bladder and the metabolic syndrome in women? A systematic review of observational studies. Int J Clin Pract 2015;69:199-217.

29. Zacche MM, Giarenis I, Thiagamoorthy G, Robinson D, Cardozo L. Is there an association between aspects of the metabolic syndrome and overactive bladder? A prospective cohort study in women with lower urinary tract symptoms. Eur J Obstet Gynecol Reprod Biol 2017;217:1-5.

30. Azadzoi KM, Tarcan T, Kozlowski R, Krane RJ, Siroky MB. Overactivity and structural changes in the chronically ischemic bladder. J Urol 1999;162:1768-1778.

31. Kennedy C. ATP as a cotransmitter in the autonomic nervous system. Auton Neurosci 2015;191:2-15.

32. Jo JK, Lee S, Kim YT, Choi HY, Kim SA, Choi BY, Moon HS. Analysis of the risk factors for overactive bladder on the basis of a survey in the community. Korean J Urol 2012;53:541-546.

33. Milsom I, Coyne KS, Nicholson S, Kvasz M, Chen Cl, Wein AJ. Global prevalence and economic burden of urgency urinary incontinence: a systematic review. Eur Urol 2014;65:79-95.

34. Üçer 0 , Demir Ö, Zeren MF, Ceylan $Y$, Çelen I, Zümrütbaş $A E$, Temeltaş $G$, Bozkurt O, Günlüsoy B, Çelik O, Ekin G, Mertoğlu O; Aegean Study Group of Society of Urological Surgery. Assessment of proportion of hidden patient having symptoms of overactive bladder and why has it been hidden in female outpatients admitted to hospital. Int Neurourol J 2016;20:47-52. 